\title{
Elementary School Students Perception Levels of Problem Solving Skills
}

\author{
Güneş Yavuz, Yasemin Deringöl, Çiğdem Arslan* \\ Hasan Ali Yucel Faculty of Education, Istanbul University, Turkey \\ *Corresponding Author: arslanc@istanbul.edu.tr
}

Copyright $\bigcirc 2017$ by authors, all rights reserved. Authors agree that this article remains permanently open access under the terms of the Creative Commons Attribution License 4.0 International License

\begin{abstract}
The purpose of this study is to reveal the perception levels of problem solving skills of elementary school students. The sample of the study is formed by totally 264 elementary students attending to $5^{\text {th }}, 6^{\text {th }}, 7^{\text {th }}$ and $8^{\text {th }}$ grade in a big city in Turkey. Data were collected by means of 'Perception Scale for Problem Solving Skills' which consists of two sub-dimensions. As a result of the study, the perception level of problem solving skills of elementary school students was high and there was no difference according to their genders. Perception levels of problem solving skills of students show a significant difference according to their grade levels. This difference is due to the fact that $8^{\text {th }}$ grade levels are lower scores than other grades. At the same time, there is a similar and significant relationship between students' perception scores for problem-solving skills and the sub-dimension 'Perceived willingness and commitment towards problem solving skills' scores.
\end{abstract}

Keywords Problem Solving Skills Perception, Mathematics Attitude, Elementary School Students

\section{Introduction}

Parallel to rapid technological and scientific developments in the world, the problems faced by people are multiplying and becoming complicated. It is necessary to seek and develop appropriate solutions to these problems. Problem solving is a tool for new ideas and abilities [1] a way to develop effective learning and individual skills [2]. Problem solving is one of the focus areas of 21 st century learning [3]. It involves the composition and coordination of various abilities, beliefs, attitudes, perceptions, knowledge and prior achievements. For this reason, it has an important place in teaching mathematics. There are different problem-solving approaches depending on the problem solving, the characteristics of the activities, the nature of the problem and the person who is interested with the problem.
The more traditional, rational approach is typically used and involves, e.g., clarifying description of the problem, analyzing causes, identifying alternatives, assessing each alternative, choosing one, implementing it, and evaluating whether the problem was solved or not [4].

Problem-solving skill is seen as an individual variable, and it is expressed that the individual is shaped based on his beliefs and anticipations about his problem-solving skills [5] and helps the individual to effectively adapt to the environment in which he/she live [6]. In addition to the social problems that individuals have to solve in their society, the problems most often encountered by students are related to mathematics lessons [7] and science lessons, particularly physics and chemistry [8]. Mathematics-related behaviors which are related to problem-solving skills perceptions, contained in programs ranging from pre-school education to higher education [9].

When the literature is examined, there are researches on problem solving perception in different education levels with different variables. Koç [10] analyzed perceptions of second-level elementary school students about problem solving skills and their help seeking during the learning process. She found a significant relationship between primary school students' perceptions of problem solving skills and their need for help. Sezen and Palic [11] carried out a study with the aim of revealing the levels of problem solving skills of high school students. As a result of the study, it was determined that female students perceive themselves more positively in terms of problem solving skill than male students. However, it was found that grade levels did not have a significant effect on students' perception of problem solving skills.

Problem solving skills perception usually associated with the affective area. In this study, the relationship between problem solving skill perception and mathematical success and interest towards mathematics was tried to be revealed.

The aim of this study was two-fold. The first aim was to determine the levels of perception of problem solving skills of elementary school students. The second aim was to compare the effects of perception of problem solving skills, 
mathematical success and interest towards mathematics. The present study focused on the following research questions within this general purpose:

What are the perception levels of problem solving skills of elementary school students?

Is there a significant difference between elementary school students' perception levels of problem solving skills according to gender?

Is there a significant difference between problem-solving perception scores and interest towards mathematics?

Is there a significant difference between elementary school students' perception levels of problem solving skills according to grade levels?

Is there a significant difference between elementary school students' perception levels of problem solving skills according to mathematics success?

\section{Materials and Methods}

\subsection{Participants}

Sample of the study is formed by randomly selected 264 elementary students (139 female, 125 male) from a school in İstanbul-Turkey. Thirty-six of the 5th year students $(50.0 \%)$ were female, $36(50.0 \%)$ were male; 28 of the 6 th grade students (38.4\%) were female, $45(61.6 \%)$ were male; 40 of the 7 th grade students $(55.6 \%)$ were female, 32 $(44.4 \%)$ were male; 21 of the 8 th grade students $(44.4 \%)$ were girls and $26(55.3 \%)$ were males.

\subsection{Data Collection Tools and Data Analysis}

As a means of collecting data in the study, "Perception Scale for Problem Solving Skills" developed by Ekici and Balım [12] was used to determine students' perceptions of problem solving skills. For this scale, a form consisting of 37 items was applied to 850 elementary school students. As a result of preliminary applications of the scale, 6 items which were included as scale control items were removed from the analysis. As a result of the factor analysis, 9 items were removed from the scale and analyzes were repeated. Confirmatory and descriptive factor analysis of the "Perceptions Scale for Problem Solving Skills" revealed that the scale had two factors and 22 items including 15 positive and 7 negative items prepared in 5-point Likert style. The variance values regarding the factors were determined to be $30.239 \%$ for the first factor and $9.976 \%$ for the second factor. The scale consists of two sub-dimensions, "Perception towards problem solving skills" (15 items) and "Perceived willingness and commitment towards problem solving skills" (7 items). The reliability coefficient of the scale was .88 and the reliability coefficient was .86 in this study. The statistics of the collected data for the sub-problems were made using SPSS 18.0 .
The results of the Kolmogorov-Smirnov normality test were examined to determine whether the data were fit for normal distribution before switching to the analysis process. The results of the Kolmogorov-Smirnov normality test were found to be normal for all dependent groups and parametric tests were used in this context. In the analysis of the data; unrelated group $t$ test and one way analysis of variance (ANOVA) were used depending on the variables. The analysis of the relationship between dependent variables was calculated by applying the Pearson Moments Multiplication Correlation Coefficient technique.

\section{Findings and Comments}

This section contains findings from the research. Table 1 shows the descriptive statistics of the perception levels of problem solving skills of elementary school students.

Table 1. Perception levels of problem solving skills

\begin{tabular}{|c|c|c|c|}
\hline & $\mathrm{N}$ & Mean & $\mathrm{S}$ \\
\hline 1.Sub-dimension & 264 & 60.53 & 8.99 \\
\hline 2.Sub-dimension & 264 & 25.22 & 6.28 \\
\hline Total Scale & 264 & 85.00 & 12.5 \\
\hline
\end{tabular}

Standard deviation and average was used to determine the perception levels of students problem solving skills. The average of the scale score was obtained with the division of "the difference between highest value and the lowest value into two" and addition of this value to lowest value $(110-22=88,88 / 2=44,22+44=66)$. Standard deviation is added and subtracted to the average for the calculation of the intervals $(66+12.5=78.5,66-12.5=53.5)$. Thus, middle level is obtained. The difference between the standard deviation and the average is regarded as the low level $(66-12.5=53.5)$. The value that is the sum of the standard deviation and the average is regarded as the upper level $(66+12.5=78.5)$. So as a result these are used in order to decide the limits of levels; the average score of the scale is 66 , ranging from 22 to 53.5 indicates the students with low levels, 53.5 to 78.5 indicates the students with medium levels and 78.5 to 110 indicates the high levels of perception of problem solving skills. The overall average score of the study group was 85 , indicating that the level of problem-solving perception of elementary school students was high.

Table 2 shows Independent Group t Test results which were made to determine whether the students' perceptions of problem solving scores differ according to gender variable.

As a result of analysis; there was no significant difference between the gender of the sample and the first subdimension "Perception towards problem solving skills" $(\mathrm{t}=-.688, \quad \mathrm{p}>.05), \quad$ second sub-dimension "Perceived willingness and commitment towards problem solving skills" $(\mathrm{t}=-1.110, \mathrm{p}>.05)$ and scale total scores $(\mathrm{t}=-1.009, \mathrm{p}>.05)$. 
Independent Group $\mathrm{t}$ Test was conducted to determine if the students "Perception of Problem Solving Skills" scores differ according to the answers of the question "Do you like the mathematics lesson?". Table 3 shows the data analysis results in response to this question.

As a result of analysis; there is a statistically significant difference between first sub-dimension "Perception towards problem solving skills" $(\mathrm{t}=5.699, \quad \mathrm{p}<.01), \quad$ second sub-dimension "Perceived willingness and commitment towards problem solving skills" $(\mathrm{t}=-5.882, \mathrm{p}<.01)$ and scale total scores $(t=6.925, p<.01)$. The scores of students who likes mathematics and scale sum were found higher than those who did not like this course.

One way ANOVA was performed to determine whether the Perception of Problem Solving Skills scores was differ according to the grade levels.

Table 2. Perceptions of problem solving according to gender

\begin{tabular}{|c|c|c|c|c|c|c|}
\hline & Gender & $\mathrm{N}$ & Mean & Std. Deviation & $\mathrm{t}$ & $\mathrm{p}$ \\
\hline \multirow[t]{2}{*}{ 1. Sub- dimension } & Female & 139 & 60.93 & 8.41 & \multirow{2}{*}{-.688} & \multirow{2}{*}{.492} \\
\hline & Male & 125 & 60.17 & 9.49 & & \\
\hline \multirow[t]{2}{*}{ 2.Sub-dimension } & Female & 139 & 25.68 & 6.05 & \multirow{2}{*}{-1.110} & \multirow{2}{*}{.268} \\
\hline & Male & 125 & 24.82 & 6.48 & & \\
\hline \multirow[t]{2}{*}{ Total scale } & Female & 139 & 86.61 & 13.27 & \multirow{2}{*}{-1.009} & \multirow{2}{*}{.314} \\
\hline & Male & 125 & 84.99 & 12.80 & & \\
\hline
\end{tabular}

Table 3. Perceptions of problem solving according to liking mathematics

\begin{tabular}{|c|c|c|c|c|c|c|}
\hline & Likes Mathematics & $\mathrm{N}$ & Mean & Std. Deviation & $\mathrm{t}$ & $\mathrm{p}$ \\
\hline \multirow[t]{2}{*}{ 1. Sub-dimension } & Yes & 169 & 62.76 & 7.86 & \multirow{2}{*}{5.699} & \multirow{2}{*}{.000} \\
\hline & No & 95 & 56.55 & 9.53 & & \\
\hline \multirow[t]{2}{*}{ 2.Sub-dimension } & Yes & 169 & 26.83 & 5.89 & \multirow{2}{*}{5.882} & \multirow{2}{*}{.000} \\
\hline & No & 95 & 22.36 & 5.96 & & \\
\hline \multirow[t]{2}{*}{ Total scale } & Yes & 169 & 89.60 & 11.42 & \multirow{2}{*}{6.925} & \multirow{2}{*}{.000} \\
\hline & No & 95 & 78.92 & 13.03 & & \\
\hline
\end{tabular}

Table 4. One-way ANOVA results of sub dimensions

\begin{tabular}{|c|c|c|c|c|c|c|c|c|c|c|}
\hline & Grade & $\mathrm{N}$ & Mean & $\begin{array}{c}\text { Std. } \\
\text { Deviation }\end{array}$ & & $\begin{array}{l}\text { Sum of } \\
\text { squares }\end{array}$ & $\mathrm{df}$ & Mean square & $\mathrm{F}$ & $\mathrm{p}$ \\
\hline \multirow{5}{*}{ 1. Sub-dimension } & 5 & 72 & 63.04 & 8.45 & Between groups & 1056.616 & 3 & 352.205 & \multirow{3}{*}{4.530} & \multirow{3}{*}{.004} \\
\hline & 6 & 73 & 59.34 & 9.01 & Within groups & 20215.077 & 260 & 77.750 & & \\
\hline & 7 & 72 & 61.27 & 8.31 & Total & 21271.693 & 263 & & & \\
\hline & 8 & 47 & 57.40 & 9.75 & & & & & & \\
\hline & Total & 264 & 60.53 & 8.99 & & & & & & \\
\hline \multirow{5}{*}{ 2.Sub-dimension } & 5 & 72 & 25.63 & 6.25 & Between groups & 394.382 & 3 & 131.461 & \multirow{3}{*}{3.417} & \multirow{3}{*}{.018} \\
\hline & 6 & 73 & 25.53 & 5.80 & Within groups & 10003.981 & 260 & 38.477 & & \\
\hline & 7 & 72 & 26.18 & 6.35 & Total & 10398.364 & 263 & & & \\
\hline & 8 & 47 & 22.65 & 6.7 & & & & & & \\
\hline & Total & 264 & 25,22 & 6.28 & & & & & & \\
\hline \multirow{5}{*}{ Scale Total } & 5 & 72 & 88.68 & 12.86 & Between groups & 2403.739 & 3 & 801.246 & \multirow{5}{*}{4.912} & \multirow{5}{*}{.002} \\
\hline & 6 & 73 & 84.87 & 12.28 & Within groups & 42412.227 & 260 & 163.124 & & \\
\hline & 7 & 72 & 87.45 & 12.71 & Total & 44815.966 & 263 & & & \\
\hline & 8 & 47 & 80.06 & 13.45 & & & & & & \\
\hline & Total & 264 & 85.76 & 13.05 & & & & & & \\
\hline
\end{tabular}


The difference between arithmetic mean according to grade levels as a result of one way variance analysis (ANOVA) was found to be statistically significant in "Perceived Dimension of Problem Solving Skills" $\left[\mathrm{F}_{(3-260)}=\right.$ 4.530, $\mathrm{p}<.05]$, Perceived Willingness and Commitment Towards Problem Solving Skills" $\left[\mathrm{F}_{(3-260)=} 3.417, \mathrm{p}<.05\right]$ and scale total $\left[\mathrm{F}_{(3-260)}=4.912, \mathrm{p}<.05\right]$. Post-hoc Scheffe test was used to determine which groups were significant differences after ANOVA. According to this; perceptions of $5^{\text {th }}$ grade students towards Problem Solving Skills Scale averages were found to be higher than average scores of $8^{\text {th }}$ grade students.

The average score of $7^{\text {th }}$ grade students' perceived willingness and commitment towards problem solving skills is higher than the average score of $8^{\text {th }}$ grade students. $5^{\text {th }}$ and $7^{\text {th }}$ grades the total scale scores are higher than the $8^{\text {th }}$ grades.

Table 5 shows the results of Pearson Multiplication Moment correlation analysis for the relationship between student's Perception of Problem Solving Skills and mathematics success of students.

As can be seen from Table 5, there was a significant positive correlation between the perceptions of problem solving skills $(r=.290 ; p<.01)$ the perceived willingness and commitment towards problem solving skills $(\mathrm{r}=.335 ; \mathrm{p}<.01)$ and total scale $(\mathrm{r}=.361 ; \mathrm{p}<.01)$.

Table 5. Results of Pearson correlations

\begin{tabular}{|l|c|c|c|}
\hline & $\mathrm{N}$ & $\mathrm{r}$ & $\mathrm{P}$ \\
\hline $\begin{array}{l}\text { Mathematics success } \\
\text { Perception towards problem solving } \\
\text { skills }\end{array}$ & 264 & .290 & .000 \\
\hline $\begin{array}{l}\text { Mathematics success } \\
\text { Perceived willingness and commitment } \\
\text { towards problem solving skills }\end{array}$ & 264 & .335 & .000 \\
\hline $\begin{array}{l}\text { Mathematics success } \\
\text { Scale total }\end{array}$ & 264 & .361 & .000 \\
\hline
\end{tabular}

\section{Discussion and Conclusions}

The students in the study group were found to have a high level of perception of problem solving skills. This result may suggest that the sample is successful in the problem-solving process. While Koç [10] found that elementary school students' problem-solving skills perceptions were satisfactory in her study consistent with the results of our study the problem solving scores of the research groups were higher than the average in the various studies related to problem solving $[13,14,15,16]$. In contrast to this research, many research findings show that problem solving skills and knowledge of elementary school students are not at the desired level $[17,18,19,20,21,22,23,24$, 25].

It was concluded that the students' level of perception of problem solving does not differ according to their gender. Although Koç's [10] study showed differences in perception sub-dimensions of problem solving skills of students according to gender, there was no significant difference between general problem solving skill perceptions. The findings of many researches on problem solving support this result $[26,27,28,29,30]$.

There is a significant difference between "Perceptions towards Problem Solving Skills", "Perceived willingness and commitment towards problem solving skills" dimensions and scale total scores according to their answers of the question "Do you like mathematics?". The scores of students who like mathematics and high scale sum were found to be higher than those who did not like this course. The fact that you like a lesson affects all the process; it can be said that students who likes mathematics are also successful in problem solving. In the survey conducted by Kumandaş and Kutlu [31] the level of mathematics liking is a predictor of the success of the course, and as the level of mathematics liking of the learners' increases, the degree to which they are successful is also one of the result.

The level of perception of problem solving skill by students varies according to their grade levels. $8^{\text {th }}$ grade students' problem-solving perception scores are significantly lower than other classes. In Koç's [10] study with $6^{\text {th }}, 7^{\text {th }}$, and $8^{\text {th }}$ grade students, 6th grade students' perception level on problem solving skills was found higher than $7^{\text {th }}$ and $8^{\text {th }}$ grade students. Similarly, the achievements of İflazoğlu Saban and Güzel Yüce [14] are consistent with the results that the averages of $6^{\text {th }}$ grade students are significantly higher than the average of $7^{\text {th }}$ and $8^{\text {th }}$ grade students in the confidence sub-dimension of problem solving skills. In our study, it was found that the highest average belongs to the $5^{\text {th }}$ grades when the average of the perception scores among the classes is taken into consideration. This result can be considered to be due to the general concern created by the high school transition examination they have to enter in the $8^{\text {th }}$ grades in our education system. In addition, the intensity of problem solving gains in the elementary school program may also have been influential. At the same time, there is a similar and significant relationship between students' perception scores for problem-solving skills and perceived willingness and commitment towards problem solving skills. Researches [11, 32], which show that problem-solving skills decrease as grade level increases, support the findings of the study.

There was a significant positive correlation between students' mathematics success and perception of problem solving skills, perceived willingness and commitment towards problem solving skills and scale total scores at a high level. This shows that students who are successful in mathematics can also be successful at solving problems at the same time. In Özsoy's [24] study titled "The Relationship Between Problem Solving Skills and Mathematical Success"; there is a positive relationship between comprehension, planning, plan implementation, and control scores in the problem solving skill test of students with a high level of mathematics achievement. There is a positive relationship between mathematics success and problem solving skills. The findings of Mason 
[33], Mohd and Mahmood, [30], Kaytanc1 [34] and Tertemiz [35] also support this finding.

Today, problem solving is no longer just one of many currents that have emerged in mathematics education and are forgotten. On the contrary, besides the arithmetic skills required to succeed in school and later in real life, problem solving is regarded as an integral part of the teaching program taught by most teachers [36]. Based on this importance, the recommendation for research is as follows: The reasons for the students' perception level for problem solving should not be reduced as the class levels increase, and the activities for problem solving skills should be increased. Heppner and Krauskopf [37]assume that self-perceived problem-solving skill serves a central function in the way a person perceives and experiences different aspects of dealing with problematic situations. However, it is expected to be reversed, the increase at the grade level caused decrease at the perception of problem-solving skills in the current study. Noushad [38] in a similar way emphasized that children's perceptions of their academic abilities decline precipitously during school. In order to prevent this situation, qualitative or mixed studies can be arranged to investigate the causes of these increase more deeply. Depending on the results obtained from these studies, empirical studies can be carried out to improve the perception of problem solving skills.

\section{Acknowledgements}

This work was supported by Scientific Research Project Coordination Unit of Istanbul University. Project number: BEK-2017-26006

\section{REFERENCES}

[1] Y. Yazgan, Ç. Arslan, Mathematical Non-routine Problem Solving Strategies and Examples, Pegem Akademi, Ankara, 2016.

[2] F. Kaptan, H. Korkmaz, Türkiye'de Hizmet Öncesi Öğretmenlerin Problem Çözme Becerilerine Yönelik Algıları Üzerine Bir İnceleme. Online available from http://journal.qu.edu.az/article_pdf/1028_438.pdf Miller, M. and Nunn, G. D. (2003). Using Group Discussion to İmprove Social Problem Solving and Learning, 2002.

[3] K. Kay, $21^{\text {st }}$ Century Skills: Why they matter, what they are, and how we get there. Foreword in: $21^{\text {st }}$ Century Skills: Rethinking how students learn, J. Bellanca and R. Brandt (eds.) US: Learning Tree, 2010.

[4] M.Uslu, Ç.Girgin, The effects of residential conditions on the problem solving skills of university students, Procedia Social and Behavioral Sciences, 2, 3031-3035, 2010.

[5] P.P. Heppner, T.E. Witty, W.A.Dixon, Problem solving appraisal: helping normal people lead better lives, The Counseling Psychologist 32(3), 466- 472, 2004.
[6] N. Senemoğlu, Gelişim ve Öğrenme, Pegem Akademi, Ankara, 2009.

[7] A. Ç. Biber, A.Y.Kutluca, Investigating problem solving skill perceptions of students at different institutions in terms of various variables, Abant İzzet Baysal Üniversitesi Eğitim Fakültesi Dergisi, 13(2), 276-288, 2013.

[8] A.O. Ogunleye, Teachers' and students' perceptions of students' problem solving difficulties in physics: implications for remediation. Journal of College Teaching \& Learning, 6(7), 85-90, 2009.

[9] Y. Baykul, İlköğretimde matematik öğretimi: 6.-8. Sınıflar, Ankara: Pegem Yayıncılık, 2009.

[10] C. Koç, Perceptions of primary school students for problem solving skills and their help-seeking during learning process, Kastamonu Eğitim Dergisi, 23(2), 659-678, 2015.

[11] G.Sezen, G. Paliç, Lise öğrencilerin problem çözme becerisi algilarinin belirlenmesi, 2 nd International Conference on New Trends in Education and Their Implications , 27-29 April, 2011 Antalya-Turkey, 2011.

[12] D.İ Ekici, A.G. Balım, Problem solving skills perception scale for secondary students: a study of validity and reliability, YYU Journal of Education Faculty, 10(1), 67-86, 2013.

[13] A. Desoete, H.Roeyers, A. Buysse, Metacognition and mathematical problem solving in grade, 3. Journal of Learning Disabilities, 34(5), 435-447, 2001.

[14] A. İflazoğlu Saban, S. Güzel Yüce, Problem Solving, metacognition and epistemological beliefs in 6th, 7th and 8th grade students, International Journal of Human Sciences [Online]. (9)2, 1402-1428, 2012.

[15] C. Gama, Helping students to help themselves: A pilot experiment on the ways of increasing metacognitive awareness in problem solving. Proceedings of CINTEC International Conference. (to appear) Aveiro, Portugal, July, 2001.

[16] R. Hollingworth, C. McLoughlin, Developing science students' metacognitive problem solving skills online, Australian Journal of Educational Technology, 17, 50-63, 2001.

[17] Ç. Arslan, M. Altun, Learning to Solve Non-Routine Mathematical Problems, İlkögretim Online, 6 (1), 50-61, 2007.

[18] P. D. Artut, K. Tarım, Investigation of The Elementary School Students' Problem Solving Levels, Problem Solving Strategies And Error Types In The Nonroutine Word Problems, Journal of Çukurova University Instıtue of Social Science, 15 (2), 39-50, 2006.

[19] İ. Karataş, B. Güven, 8. Sınıf Öğrencilerinin Problem Çözme Becerilerinin Belirlenmesi: Bir Özel Durum Çalışması, Milli Eğitim Dergisi, C. 163, 2004.

[20] M.MacGregor, K. Stacey, Learning to formulate equations for problems, PME 20, July 8-12, Valencia, Spain, Vol 3, 289303, 1996.

[21] K. Stacey, M. MacGregor, Learning the algebraic method of solving problems, Journal o Mathematical Behavir. 18 (2), 149-167, 2000.

[22] F.M. Özcan, İlköğretim 6-7-8. Sınıf Öğrencilerinin Problem 
Çözme Stratejileri ve Matematiksel Modellemenin Problem Çözmedeki Yeri ve Önemi, Yüksek Lisans Tezi, Dokuz Eylül Üniversitesi Eğitim Bilimleri Enstitüsü, İzmir, 2005.

[23] A. Özmen, Problem Çözme ve Matematiksel İfade Etme, Selçuk Üniversitesi Fen Bilimleri Enstitüsü, Yüksek Lisans Tezi, Konya, 2003.

[24] G. Özsoy, The Relationship Between Problem Solving Skills and Mathematical Achievement, GÜ, Gazi Eğitim Fakültesi Dergisi, 25 (3), 179-190, 2005.

[25] Y. Yazgan, Observations About Fourth And Fifth Grade Students' Strategies To Solve Non-Routine Problems, Elementary Education Online, 6(2), 249-263, 2007.

[26] G. Balcı, İlköğretim 5. Sınıf Öğrencilerinin Sözel Matematik Problemlerini Çözme Düzeylerine Göre Bilişsel Farkındalik Becerilerinin İncelenmesi, Çukurova Üniversitesi Sosyal Bilimler Enstitüsü, Yayımlanmamış Yüksek Lisans Tezi, Adana, 2007.

[27] E.Zakaria, N.Yusoff, Attitudes and Problem-solving Skills in Algebra among Malaysian College Students, European Journal of Social Sciences, 8 (2), 232-245, 2009.

[28] C. Fitzpatrick, Adolescent Mathematical Problem Solving: The Role of Metacognition, Strategies and Beliefs, Paper presented at the Annual Meeting of the American Educational Research Association, New Orleans, LA, April [ED374969], 1994.

[29] J. S. Hyde, E. Fennema, S. J. Lamon, Gender Differences in Mathematics Performance: A Meta-Analysis, Psychological Bulletin, 107(2), 139-155, 1990.

[30] N. Mohd, T.F.P.T. Mahmood, The Effects of Attitude Towards Problem Solving in Mathematics Achievements, Australian Journal of Basic and Applied Sciences, 5(12), 1857-1862, 2001
[31] H. Kumandaş, Ö. Kutlu, Performance Tasks of Primary Grade Fifth Grade Students Love Academic Achievement and Lessons of Attitudes Examination by Situation, Journal of Measurement and Evaluation in Education and Psychology, 2(2), 172-181, 2011

[32] J. Cai, Singaporean Students' Mathematical Thinking in Problem Solving and Problem Posing: An Exploratory Study. International Journal of Mathematical Education in Science and Technology, 34 (5), 719-737, 2003.

[33] L. Mason, High School Students' Beliefs about Maths, Mathematical Problem Solving and Their Achievement in Maths: A Cross Sectional Study, Educational Psyhology, 23(1), 73-85, 2003.

[34] N. Kaytancı, İlköğretim Dördüncü Sınıf Matematik Öğretiminde Öğrencilere Problem Çözme İle İlgili Kritik Davranışların Kazandırılmasında Öğrenme Düzeyinin Belirlenmesi. Pamukkale Üniversitesi Sosyal Bilimler Enstitüsü, Yayımlanmamış Yüksek Lisans Tezi, Denizli, 1998.

[35] N. Tertemiz, İlkokulda Aritmetik Problemleri Çözmede Etkili Görülen Bazı Faktörler, Yayımlanmamış Doktora Tezi. Hacettepe Üniversitesi Sosyal Bilimler Enstitüsü, Ankara, 1994.

[36] L. Akgün, T. Kar, M.F. Öcal, Matematikte Problem Çözme 3-6. Sinıflar İçin, Pegem Akademi, Ankara, 2016.

[37] Heppner, P. P., Krauskopf, C. J. An information-processing approach to personal problem solving. The Counseling Psychologist, 15, 371-447, 1987.

[38] Noushad, P.P. Cognitions about Cognitions: The Theory of Metacognition, Online submission. Retrieved (2017, September, 19) from https://eric.ed.gov/?id=ED502151, 2008. 